ISBN 978-93-86878-09-0

11th International Conference on Management, Law, Economics and Interdisciplinary Studies

(MLEIS-18)

Bali (Indonesia) Jan. 12-13, 2018

\title{
The Infrastructure Development and Competitiveness of Smes in Implementation of Creative Industries of Palembang City
}

\author{
Kristina Sedyastuti ${ }^{1}$ \\ Universitas Bina Darma
}

\begin{abstract}
This study aims to describe and analyze the implementation of infrastructure development and competitiveness of SMEs in order to accelerate regional development through creative industries in the city of Palembang. The research focuses on: road construction, education sector development, economic development, supervision and coordination among implementers and enhancing the competitiveness of SMEs as craftsmen who have a large amount of participation in increasing local revenue and at the same time improving the economy of Palembang city. The research used descriptive method with qualitative approach, the data used is primary data through interview with questionnaire and secondary data through performance accountability report of government agencies and SMEs songket. Method of data analysis using interactive data analysis model Miles and Huberman (2005). Based on the analysis results obtained that the implementation of infrastructure development in the implementation of the role of SMEs in the Creative Industry in the city of Palembang. The result of the research shows the increasing of development role and the trigger of SMEs craftsmen where the city of Palembang is designated as the center of Creative industry until 2025. The construction of handicraft centers and awareness of SMEs perpetrators for the development can add 80 percent of facilities and infrastructure in the area. This success has not reached the target of 100 percent due to limited budget allocation. This factor becomes the main obstacle to the construction of infrastructure in Palembang city. In addition, the process of disbursement of funds becomes an additional cause why the construction of the infrastructure is inhibited.
\end{abstract}

Keywords: infrastructure, creative industry, competitiveness

\section{Introduction}

The Infrastructure Development In order to accelerate development in a region must be supported by various factors, including infrastructure development. Todaro, 2000: 218) that infrastructure development has an important role in realizing development objectives such as equitable distribution of development and its results towards the creation of social justice for all people. Infrastructure development is one of the decisive factors in supporting the smooth development and development of a region, because without adequate infrastructure tend to be in the process of development will be hampered, even result are less than optimal. In terms of infrastructure development in the regions related to the implementation of government tasks, development and public services. The importance of infrastructure development for a region is characterized by the value of benefits and usefulness to the infrastructure. Especially can be seen from the accessibility that connects between areas of authority, economic mobility, transportation and so forth. Small and medium enterprises (SMEs) is one of supporting economic growth of a region. With the increasingly competitive business world today, SMEs are required to improve local competitiveness by cleaning, preparing, and trying to win this competition (Ulum, 2010). One way to achieve that goal is to adopt and implement an information system (SI). But there is often a failure in the utilization of information systems. Some studies show that implementation failures are dominated by human factors such as: incompatible with new work culture, ethics and policy and the lack of expertise, this is what SMEs are calling the competitiveness of. One of the sectors that cultivate small and medium enterprises that is very possible to be developed is 
the creative industry. The creative industry is an industry derived from the utilization of creativity, skills and individual talents to create prosperity and employment through the creation and utilization of the creative and creative power of the individual (Ministry of Trade of the Republic of Indonesia, 2007).

Creative human resources and cultural heritage wealth is a strong capital for the Indonesian nation to compete in the creative industry. This industry sector further intensified the use of market information, creativity and supported by creative human resources. With this stock of SMEs are expected to compete with large industries that are often more efficient and cheaper production costs. Creative industry is divided into 14 sectors, namely: advertising, publishing and printing. TV and radio, film, video and photography, music, performing arts, architecture, design, feysen, crafts, art bases, interactive games, computer and software services, research and development. The creative industry is one of the economic supporting communities in Palembang, South Sumatra. Of the 14 sub-sectors that exist in the creative industry, one of which is the creative industry songket craft that will be the focus in research. Improvement of the creative industry in Palembang City contributes greatly to community life in the form of job creation, poverty reduction and empowerment of small and medium enterprises. To win the competition there are SMEs are required to always improve performance with resources owned.

\section{Literature Review}

According to the Central Bureau of Statistics (BPS) of Palembang City, predicted that the growth of Micro, Small and Medium Enterprises (SMEs) in this year will increase to 100 percent or reach 400 thousand SMEs, from 200 thousand based on data from 2006. From the results survey, in which all types of businesses participated in the survey, including online business actors and increasingly mushroomed resellers support economic growth (http://www.bisnissyariah.co.id/2016/05/bpsmemprediksi-pertumbuhan-umkm-palembang-meningkat-100-persen)

Small and medium entrepreneurs (SMEs) in South Sumatera Province must learn about trade management, and business actors themselves must be smart in managing their business in order to continue to grow and develop. South Sumatera Provincial Government itself through the Department of Trade has done various steps, including training and fostering of SMEs in order to grow and become a big business. Socialization Activity Increase Domestic Product Usage in Educational Sector, Small and Medium Small Scale Micro Small Medium Enterprise Electronic Systems, Technical Guidance for Micro Small Medium Enterprises (SMEs) and Socialization of Alcoholic Beverage Policy, ECommerce and Modren Stores, this socialization is conducted so that SMEs can grow by utilizing banking in management and business development. Many things should be known by SMEs about trade, for that socialization is very big benefits, especially for the perpetrators of SMEs. With the expectation of SMEs can become the backbone of economy. Where through socialization expected domestic trade activity can be improved through domestic trade transactions. In addition, the Ministry of Trade itself continues to make efforts to encourage small and medium-sized micro enterprises to increase their activities through local-scale exhibitions. Development of infrastructure in the province of South Sumatra is currently massive done.

Implementation of Infrastructure Development in the Framework of Accelerating the Development of Development Areas of Road Facilities In order to facilitate the implementation of government tasks and community activities, it needs to be supported by adequate infrastructure development. One of them is the development of road facilities and infrastructure. Because with adequate road facilities, undoubtedly the implementation of government tasks and public interest can be implemented effectively. On the other hand can facilitate the accessibility of the population in all forms of activities related to community life. Road is an infrastructure that is vital to support the smoothness of transportation facilities as well as driving the economy of the community as well as the arterial route 
for local transportation, because it is appropriate the construction of roads and bridges get greater attention, so public expectations to obtain ease of access can be realized. In accordance with its function, road conditions greatly affect the smooth relationship between villages, as well as between districts. Based on the above conclusions, theoretical implications according to Abdul Wahab (1997) as well as Mazmanian Sabatier (1981) have materialized as stipulated in public policy, ie the process of policy implementation begins when the policy objectives are established, the implementation programs have been created, and funds have been allocated for the achievement of the policy objectives In the development of health infrastructure has an important position to support the implementation of an effective government, because with adequate health infrastructure undoubtedly the health of the state / government and community will be more secure.

\section{Research Methodology}

The approach used in this research is descriptive and analyzed qualitatively. Descriptive-qualitative research intends to describe the reality of an event to get a picture of the phenomena that occur in the field. The focus of this research includes the implementation of infrastructure development and the factors that support and impede the implementation of infrastructure development in the acceleration of regional development in the city of Palembang. The data collected consist of primary data and secondary data. Primary data is obtained from other parties namely the Office of Cooperatives and SMEs and Industry and Trade Agency in Palembang and secondary data obtained from all respondents creative craft industry in Palembang.

\section{Results and Discussion}

Therefore it is appropriate if it gets more attention from the government. so that the degree of public health and state / government organizers can perform their duties more effectively. However, the development of health infrastructure is very urgent to improve public health. Because it is appropriate if the health infrastructure built according to community needs to be accessed easily, cheap and quality. Implementation of Infrastructure Development (Jimmy Herman) The existence of infrastructure development in the field of health indicates that infrastructure has been provided, but still lack of accompanied by competent medical facilities and personnel in their respective fields. The sub-district government has coordinated with the vertical agency in charge related to the limited resources of the apparatus each year in searching for solutions related to the problems faced to equip the technical personnel. with the presence of good coordination of this contribution to support the smoothness of health services to the community in the city of Palembang.

Theoretically according to Anderson (1997) that the implementation of the policy seen from who implements the policy and impact. It can be explained that every policy that has been established at the time of implementation is always preceded by the appointment of the implementing unit by Anderson called "administrtaive unit" ie the public bureaucracy from the top level to the lowest level and automatically implement the policy set. Equally important is the Education Infrastructure Development which is one of the government programs that must be continuously improved because considering the success of the development that is going to and continue to be done can not be separated from the influence of the quality of human resources, whether within the body of the government and the community itself. Serious attention by the City Government of Palembang not only on the construction of the building, teaching and learning facilities, but also the quality of teachers / teachers in order to produce quality education. The existence of educational infrastructure development aims to ensure that students in Palembang City area get the widest opportunity to attend quality education and teaching, so that the development of education infrastructure is directed to build and complement the existing educational facilities. Factors Supporting and Inhibiting Infrastructure Development in Palembang City. 
In simple terms Lineberry's theory that the implementation process includes all actions between the policy statement and the actual impact. The implementation process has elements to define implementation responsibilities, define goals, coordinate resources and allocate resources for perfection or to achieve goals. coordinate (eJournal Administrative Reform, Volume 2, Number 4, 2014: 2281-2291). Infrastructure development in the economic field in order to achieve the level of community welfare is always improved. Economic development is not only to create a regulatory system governing economic and trade centers, but also to be supported by the availability of a reconomy infrastructure capable of supporting the trade process itself, especially in society so that the wheels of community economy can be done as well as possible. Recognizing that the development of economic facilities is needed by the community and economic actors in the region, the Government of Palembang City has poured the formula in the short-term plan made in the strategic plan in creating economic centers and trades and traditional markets that can improve people's economic activities. The emphasis on this market or market center is because it is explicitly stated that the existence of a trade or market center will be able to invite the gathering of trade and industry players, and various commodities, so that the market will become a growing economic center. With the existence of this infrastructure development has enormous benefits for the community in empowering the economy of the community. According to Van Meter and Van Horn (1985: 447), that the Implementation of the policy includes actions by either government, individual or group, which are intended to achieve the objectives specified in the decision. This includes efforts to mantrasform the decision into the stage operational to achieve major or minor changes as determined in the decision.

\subsection{Supporting Factors Include}

a. Law No. 33 of 2004 on the financial balance between the central government and regional governments. Based on the policy, Palembang City can develop infrastructure of Implementation of Infrastructure Development (Jimmy Herman) 2289 in various areas of Palembang City in the framework of equitable regional development.

b. Support all citizens against government policy through proposals submitted to the district government regarding the need for infrastructure development in Palembang City, in order to accelerate regional development.

c. Conducive atmosphere and community environment so that infrastructure development in Palembang city can be implemented.

\subsection{Inhibiting Factors Include:}

a. Limited regional budget for infrastructure development such as road construction, education sector, health sector and economic field, so that the acceleration of regional development can not be actualized.

b. Limited quality of human resources owned by the contractors so that the results of infrastructure development is less than optimal.

c. The low accessibility of transportation to the location for which the infrastructure will be built will require a higher cost.

d. Lack of public awareness of the utilization and maintenance of infrastructure where the need for community cooperation, especially the location and land that must be freed for the development.

e. The funding factors are often late so that development projects often stop so as not to reach the target time of the development. 


\section{Conclusion}

The existence of infrastructure development in Palembang City is implemented quite effectively and able to add some facilities and infrastructure, not only road infrastructure, health infrastructure, educational infrastructure, but also add economic infrastructure. Although infrastructure development undertaken in the Palembang city area is not yet optimal, but the actions taken by the Government have brought about better change, and make the atmosphere and community environment more secure and comfortable. Factors supporting infrastructure development in Palembangt include Law No. 33 of 2004 on financial balance between central government and local government, Government ability in approaching with vertical organizational leadership ie district government and coordination with some related government officials, and community participation in improving infrastructure development.

While the factors that hamper infrastructure development in Palembang city are the limited allocation of infrastructure development budget such as road construction, education, health and economic infrastructure, low transportation accessibility so that bigger cost is required, and funding factor is often late so that applicative development lack of infrastructure and lead to less effective results achieved.

\section{Acknowledgements}

Thank the leaders of Universitas Bina Darma who have supported me in doing this research so that I can follow the conferences held by BELRG (Business, Education \& Law Research Group).

\section{References}

[1] _ Undang-undang Nomor. 32 dan 33 tahun 2004, tentang pemerintahan daerah dan perimbangan keuangan antara pemerintah pusat dengan pemerintah daerah, Indonesia. Jakarta

[2] Anderson, J.E. 1979. Public Policy Making Holt, Rinehart and Winston. New York. (Book style)

[3] Jimmy Herman1, Nur Fitriyah2 , Rita Kalalinggi3 2014, IMPLEMENTASI PEMBANGUNAN INFRASTRUKTUR DALAM RANGKA PERCEPATAN PEMBANGUNAN DAERAH DI KECAMATAN SEKOLAQ DARAT KABUPATEN KUTAI BARAT. eJournal Administrative Reform, 2014, 2 (4): 2281-2291 ISSN 2338-7637, ar.mian.fisip-unmul.ac.id @ Copyright 2014. (Periodical style)

[4] Mazmanian, Daniel and Paul A. Sabatiar (eds), 1981. Effectivly Policy Implementation. Lexington Mass.

[5] Milles B, Mathew dan A.Michaell Huberman. 2005. Analisis Data Kualitatif. Buku Sumber Tentang metode-metode Baru. Diterjemahkan oleh TR. Rohidi Jakarta: Penerbit Univesitas Indonesia. Jakarta. . (Book style)

[6] Todaro, M. P. 1992. Ekonomi Pembangunan di Dunia ke Tiga. Terjemahan dari: Haris M. Erlangga, Jakarta. (Book style)

[7] Ulum, Ihyaul, (2010), "Memenangi Persaingan China - ASEAN Free Trade Area (CAFTA) Melalui Optimalisasi Pengelolaan Intellectual Capital", Paper ini dipresentasikan pada seminar nasional di FE - UT Tangerang Selatan, 1 Oktober 2010, diakses tanggal 20 April 2011 dari www.google.com. (Presented Conference Paper style) (Book style with paper title and editor)

[8] Van Meter, D.S. and C.E. Van Horn, 1975. The Policy Implementation Process: Conceptual Framework. USA. (Book style)

[9] eJournal Administrative Reform, Volume 2, Nomor 4, 2014: 2281-2291

[10] http://www.bisnissyariah.co.id/2016/05/bps-memprediksi-pertumbuhan-umkm-palembang-meningkat-100-persen 